\title{
Effect of 19-Norandrostenololylaurate on Serum Testosterone Concentration, Libido, and Closure of Distal Radial Growth Plate in Colts
}

\author{
By E. Koskinen ${ }^{1}$ and T. Katila ${ }^{2}$
}

${ }^{1}$ Agricultural Research Centre, Equine Research, Ypäjä, and ${ }^{2}$ Animal Reproduction, Faculty of Veterinary Medicine, University of Helsinki, Finland.

\begin{abstract}
Koskinen E. and T. Katila: Effect of 19-norandro stenololylaurate on serum testosterone concentration, libido, and closure of distal radial growth plate in colts. Acta vet. scand. 1997, 38, 59-67. - The long-term effect of anabolic steroid was investigated in 3 experiments. In experiment $\mathrm{I}, 500 \mathrm{mg}$ of 19 -norandrostenololylaurate was given to 5 colts and a dose of $100 \mathrm{mg}$ to another 5 colts every 3 rd week. Six colts served as untreated controls. The animals were 12-16 months old at the start, and 24 months at the end of treatment. In experiment II, a dose of $1 \mathrm{mg} / \mathrm{kg}$ was given every 3rd week to 4 colts and $0.3 \mathrm{mg} / \mathrm{kg}$ every week to another 4 colts. Six colts served as controls. The colts were treated from 7 months to 12 months of age. In experiment III, $1 \mathrm{mg} / \mathrm{kg}$ of steroid was given every 3 rd week to 3 foals between 3 and 8 months of age. Three foals were used as controls. Libido and hCG-induced serum testosterone concentrations were studied after the cessation of treatments, up to 3 or 4 years of age. Closure of the right distal radial growth plate was determined between 21 and 36 months of age.

Treated colts had lower testosterone levels 4.5 months after cessation of treatment in experiment I $(p<0.001)$ and experiment II $(p<0.05)$ when compared with the corresponding control groups. Two years after treatments in experiment I, hCG-induced testosterone levels were higher in treated colts than in untreated controls, but the difference was not statistically significant. The treatments had no effect on libido. The anabolic steroid treatment did not cause premature closure of epiphyseal growth plates in any of the experiments, but closure appeared to be delayed. It was concluded that anabolic steroids have long term effects on reproduction. Their influence on serum testosterone can last for years after cessation of treatment, and they can delay the closure of growth plates which can cause increased susceptibility to cartilage injury during exercise.
\end{abstract}

stallion; anabolic; steroid; $h C G$; epiphysis.

\section{Introduction}

Treatment with anabolic steroid causes malelike behavior in mares (Maher et al. 1983). Testosterone has been used to increase libido in the stallion. However, administration of high doses decreases serum testosterone levels and libido. Exogenous androgens suppress gonadotropin release from the pituitary, which leads to decreased endogenous testosterone production. During and shortly after cessation of anabolic steroid treatment, libido might therefore be decreased because of low endogenous testosterone concentrations (Davis 1981, Garcia et al. 1987).

In stallions, no controlled trials have been carried out to investigate the long-term effects of 
anabolic treatment on libido or serum testosterone concentrations. Usually, animals have been castrated shortly after treatment (Carson \& Thompson 1979, Squires et al. 1981 and 1982, Garcia et al. 1987). In one study only, stallions were followed for 3 months after cessation of treatment. Libido was not affected by testosterone propionate treatment or cessation of treatment (Squires et al. 1981).

In man, reduced plasma testosterone concentrations have been detected after anabolic steroid treatment (Blanchard 1985), but in stallions testosterone concentrations were not decreased shortly after treatment with anabolic steroid (Carson \& Thompson 1979, Garcia et al. 1987). Single testosterone measurements, however, may fail to reveal differences because testosterone secretion is episodic in nature. There were 3-fold differences between testosterone concentrations over a $24 \mathrm{~h}$ sampling period in stallions (Ganjam 1979). Frequent blood sampling is required for dependable serum testosterone determination, but this is very laborious. Serum testosterone concentrations rise 20- to 30-fold after hCG administration (Silberzahn et al. 1988) or GnRH (Clay et al. 1988) reaching peak levels 2 to 3 days after injection (Silberzahn et al. 1988). This facilitates reliable single testosterone measurements which give indication of tes tosterone production by the testes.

It is commonly claimed that large quantities of testosterone or anabolic steroids early in life hasten closure of the epiphyseal plates and thus prevent further growth in length of bones ( $\mathrm{To}$ bin 1978, Davis 1981). However, no controlled studies supporting this claim have been reported. The opposite has, in fact, been observed (Herring 1981, Saastamoinen \& Koskinen 1993). The aim of the present study was to examine the long-term effect of an anabolic steroid on serum testosterone levels, sexual arousal and closure of the distal radial growth plate in sexually non-mature colts.

\section{Materials and methods}

The animals used were Finnhorse colts raised for trotting and riding. The Finnhorse is a coldblooded breed. Adult horses weigh 500-600 $\mathrm{kg}$. The colts were not trained but light exercise started at 3 years of age. They were kept on pasture from June to September. During winter they were in an unheated barn, with free access to a paddock. Three experiments were carried out. The first started in autumn, the second at the start of the following year, and the third in autumn 2 years later. All colts in the 3 experiments were born in May or June except for 3 born in April, July and August. The anabolic steroid used was an injectable 19-norandrostenololylaurate preparation ${ }^{1}$. The manu facturer recommends a dose of 100-200 mg every 3rd week for adult horses, for instance to aid recovery after a severe operation. The recommended dose corresponds to a dose of $0.2-0.4 \mathrm{mg} / \mathrm{kg}$ in a $500 \mathrm{~kg}$ horse. Because it is alleged that much higher doses of steroids are used for doping than therapeutical doses, the dose chosen in experiment I was $500 \mathrm{mg}$ for colts weighing around $400 \mathrm{~kg}$ during the treatment period. Dose in experiments II and III was calculated as $\mathrm{mg} / \mathrm{kg}$ of body weight. Treatment periods varied between 5 and 12 months. Treatment protocols in experiments I-III are shown in Table 1. The examination protocols of the 3 trials are shown in Table 2. Blood samples were collected for testosterone determinations during breeding and nonbreeding seasons. Intramuscular injection of 5000 IU of hCG (Chorio-Gonadon, Orion-Farmos Oy, Finland) was used to induce rises in serum testosterone concentration. A jugular vein blood sample was drawn on day 3 after hCG injection for testosterone determination. Serum was separated, frozen, and testoste-

\footnotetext{
${ }^{1}$ Laurabolin vet ${ }^{\circledR}$, Intervet International B.V., 5830 AA Boxmeer, The Netherlands.
} 
Table 1. Number of animals, age at start and end of treatment and dosage during treatment of colts with 19norandrostenololylaurate in experiments I-III.

\begin{tabular}{cccccc}
\hline Experiment & $\begin{array}{c}\text { Number } \\
\text { of } \\
\text { animals }\end{array}$ & $\begin{array}{c}\text { Age at } \\
\text { start of } \\
\text { treatment } \\
\text { (months) }\end{array}$ & $\begin{array}{c}\text { Age at } \\
\text { end of } \\
\text { treatment } \\
\text { (months) }\end{array}$ & $\begin{array}{c}\text { Dose } \\
\text { level }\end{array}$ & $\begin{array}{c}\text { Dosage } \\
\text { inter- } \\
\text { val }\end{array}$ \\
\hline I & 6 & - & - & untreated & - \\
& 5 & $12-16$ & 24 & $100 \mathrm{mg}$ & 3 weeks \\
II & 5 & $12-16$ & 24 & $500 \mathrm{mg}$ & 3 weeks \\
& 6 & - & - & untreated & - \\
III & 4 & 7 & 12 & $1 \mathrm{mg} / \mathrm{kg}$ & 3 weeks \\
& 4 & 7 & 12 & $0.3 \mathrm{mg} / \mathrm{kg}$ & 1 week \\
& 3 & - & - & untreated & - \\
\hline
\end{tabular}

Table 2. Time of examination of serum testosterone concentration, libido, and closure of radial distal growth plate in relation to age and cessation of treatment.

\begin{tabular}{|c|c|c|c|c|c|c|}
\hline \multirow[b]{2}{*}{ Experiment } & \multicolumn{2}{|c|}{ Testosterone } & \multicolumn{2}{|c|}{ Libido } & \multicolumn{2}{|c|}{$\begin{array}{l}\text { Closure og radial } \\
\text { distal growth plate }\end{array}$} \\
\hline & $\begin{array}{c}\text { Age } \\
\text { (months) } \\
\text { treatment }\end{array}$ & $\begin{array}{l}\text { Months } \\
\text { after } \\
\text { treatment }\end{array}$ & $\begin{array}{c}\text { Age } \\
\text { (months) } \\
\text { treatment }\end{array}$ & $\begin{array}{c}\text { Months } \\
\text { after }\end{array}$ & $\begin{array}{c}\text { Age } \\
\text { (months) }\end{array}$ & $\begin{array}{c}\text { Months } \\
\text { after }\end{array}$ \\
\hline \multirow[t]{4}{*}{ I } & 28.5 & 4.5 & 24 & 0 & 21 & $-3^{a}$ \\
\hline & 48 & 24 & 36 & 12 & 28.5 & 4.5 \\
\hline & & & & & 31.5 & 7.5 \\
\hline & & & & & 36 & 12 \\
\hline \multirow[t]{3}{*}{ II } & 16.5 & 4.5 & 24 & 12 & 23.5 & 11.5 \\
\hline & & & & & 30 & 18 \\
\hline & & & & & 33 & 21 \\
\hline \multirow[t]{6}{*}{ III } & 18 & 10 & 24 & 16 & 22 & 14 \\
\hline & 20 & 12 & 29 & 21 & 24 & 16 \\
\hline & 24 & 16 & 36 & 28 & 25 & 17 \\
\hline & 28 & 20 & 41 & 33 & 26 & 18 \\
\hline & 41 & 33 & 48 & 40 & & \\
\hline & 53 & 45 & & & & \\
\hline
\end{tabular}

a 3 months before the final treatment.

rone determined later using a quantitative radioimmunoassay test (Spectria* Testosterone $\left.{ }^{[25} \mathrm{I}\right]$ Coated Tube Radioimmunoassay, Orion Diagnos tica, Finland). Sensitivity of the test was $0.1 \mathrm{nmol} / 1$ and cross-reactivity with $5 \alpha$-dihydrotestos terone was $4.5 \%$. Intra-assay and interassay coefficients of variation were $5.3 \%$ and $5.4 \%$, respectively. 
Libido was evaluated as "time to ejaculation" during the breeding season. In experiment III, libido was also evaluated during the nonbreeding season. Evaluations started at 24 months of age. Libido was determined every other day. Each animal was assessed 2-8 times during the semen collection period and the mean value per period was calculated for each colt. "Time to ejaculation" began when a colt entered the breeding hall. Ejaculation into an open ended artificial vagina (Model Krakow, Poland) marked the end of the "time to ejaculation". If a colt failed to ejaculate, the estimated time was not included in the calculation. Failure to ejaculate occurred randomly in all groups.

Closure of the right distal radial growth plate was determined from craniocaudal radiographs between 21 and 36 months of age. Lack of translucency of the growth plate, particularly at plate ends, was considered as closure of the plate. For technical reasons, one radiograph relating to one colt in the $500 \mathrm{mg}$ group in experiment $I$ is lacking.

\section{Statistical analysis}

Analysis of variance for repeated measurements and one-way analysis of variance followed by Tukey's test was used to assess treatment effects on serum testosterone concentration and on time to ejaculation. The significance of effects of treatment on closure of growth plates was tested using the chi-squared test.

\section{Results}

\section{Experiment I}

Four and a half months after the last treatment, when the colts were aged 28.5 months, mean hCG-induced testosterone levels were significantly lower in the treated groups compared with the controls $(p<0.001)$. Two years after treatment, when the colts were 48 months old, testosterone levels were higher in the treated groups than in the control group. However, the variation was large at this time point and the difference was not statistically significant. The changes in serum testosterone concentration from 28 months to 48 months were significantly different between the control group and the 500 mg group $(\mathrm{p}<0.05)$ (Table 3$)$.

At the time of the final treatment, at age 24 months, time to ejaculation was similar in the $500 \mathrm{mg}$ group (111 sec), $100 \mathrm{mg}$ group (71 sec) and control group $(86 \mathrm{sec})$. One year later, the situation was the same (times $138 \mathrm{sec}, 87 \mathrm{sec}$ and $98 \mathrm{sec}$, respectively).

Table 4 shows closure of the right distal growth plate. Four and a half months after treatment, when the colts were aged 28.5 months, closure of the growth plate had occurred more often in the control group than in the treated groups $(p<0.05)$. At age 31.5 months, the difference was similar but no longer significant $(p=0.089)$. At 36 months, the difference was even smaller.

\section{Experiment II}

Serum testosterone concentrations were determined 4.5 months after the final treatment, when the colts were aged 16 months. The mean hCG-induced testosterone levels were relatively low in all groups, but lowest in the treated groups $(\mathrm{p}<0.05)$ (Table 5).

Time to ejaculation was similar in all groups at age 24 months, 12 months after the final treatment: $101 \mathrm{sec}$ in the control group, $95 \mathrm{sec}$ in the $1 \mathrm{mg} / \mathrm{kg}$ every $3 \mathrm{rd}$ week group and $137 \mathrm{sec}$ in the $0.3 \mathrm{mg} / \mathrm{kg}$ every week group.

At 23.5 months of age, no closure of the right distal radial growth plate was observed in any of the groups. At 30 months of age, 5 out of 6 in the control group, 3 out of 4 in the $1 \mathrm{mg} / \mathrm{kg}$ every 3 rd week group, and 2 out of 4 in the 0.3 $\mathrm{mg} / \mathrm{kg}$ every week group showed closure of the growth plate (Table 6). The difference between groups was not statistically significant. 
Table 3. Mean (SEM) serum testosterone concentration (nmol/l) on day 3 after hCG-injection ( $5000 \mathrm{IU} \mathrm{im}$ ) in experiment I.

\begin{tabular}{lll}
\hline Age of colts (months) & 28.5 & 48 \\
Months after treatment & 4.5 & 24 \\
Month & October & May \\
\hline Controls (6 colts) & $23.50(2.78)$ & $7.17(1.89)$ \\
100 mg every 3rd week (5 colts) & $12.80(2.24)^{*}$ & $14.60(7.23)$ \\
500 mg every 3rd week (5 colts) & $5.20(1.59)^{*}$ & $15.40(5.97)$ \\
\hline
\end{tabular}

* Statistically significant difference $(\mathrm{p}<0.05)$ in relation to controls.

Table 4. Number of colts with closed epiphyseal plates at different times in experiment I.

\begin{tabular}{lccc}
\hline Age of colts (months) & 28.5 & 31.5 & 36 \\
Months after treatment & 4.5 & 7.5 & 12 \\
\hline Controls (6 colts) & $5 / 6$ & $6 / 6$ & $6 / 6$ \\
$100 \mathrm{mg}$ every 3rd week (5 colts) & $2 / 5$ & $3 / 5$ & $4 / 5$ \\
$500 \mathrm{mg}$ every 3rd week (5 colts) & $0 / 4^{* a}$ & $2 / 5^{*}$ & $3 / 5$ \\
\hline
\end{tabular}

* Statistically significant difference $(\mathrm{p}<0.05)$ in relation to controls.

a Radiograph for one colt is missing.

\section{Experiment III}

Serum testosterone concentrations were determined 6 times between 18 and 53 months of age. The highest concentrations of testosterone were found at age 24 months, during the breeding season. The rest of the measurements were made during the nonbreeding season. Group profiles did not differ significantly between treatments (Table 7).

In both groups, time to ejaculation was short during the breeding season $(88 \mathrm{sec}$ at 3 years of age, and $94 \mathrm{sec}$ at 4 years of age in the control
Table 5. Mean (SEM) serum testosterone concentration $(\mathrm{nmol} / \mathrm{l})$ on day 3 after hCG-injection (5000 IU im) in experiment II.

\begin{tabular}{lc}
\hline Age of colts (months) & 16 \\
Months after treatment & $\begin{array}{c}4.5 \\
\text { October }\end{array}$ \\
Month & 4.50 (0.89) \\
\hline Controls (6 colts) & $1.25(0.48)^{*}$ \\
$1 \mathrm{mg} / \mathrm{kg}$ every 3rd week (4 colts) & $1.75(0.25)^{*}$ \\
$0.3 \mathrm{mg} / \mathrm{kg}$ every week (4 colts) & \\
\hline
\end{tabular}

* Statistically significant difference $(\mathrm{p}<0.05)$ in relation to controls.

Table 6. Number of colts with closed epiphyseal plates at different times in experiment II.

\begin{tabular}{llll}
\hline Age of colts (months) & 23.5 & 30 & 33 \\
Months after treatment & 11.5 & 18 & 21 \\
\hline Controls (6 colts) & $0 / 6$ & $5 / 6$ & $6 / 6$ \\
$1 \mathrm{mg} / \mathrm{kg}$ every 3rd week (4 colts) & $0 / 4$ & $3 / 4$ & $4 / 4$ \\
$0.3 \mathrm{mg} / \mathrm{kg}$ every week (4 colts) & $0 / 4$ & $2 / 4$ & $4 / 4$ \\
\hline
\end{tabular}


Table 7. Mean (SEM) serum testosterone concentration (nmol/l) on day 3 after hCG-injection (5000 IU im) in experiment III.

\begin{tabular}{|c|c|c|c|c|c|c|}
\hline $\begin{array}{l}\text { Age of colts (months) } \\
\text { Months after treatment } \\
\text { Month }\end{array}$ & $\begin{array}{l}18 \\
10 \\
\text { Nov }\end{array}$ & $\begin{array}{l}20 \\
12 \\
\text { Jan }\end{array}$ & $\begin{array}{c}24 \\
16 \\
\text { May }\end{array}$ & $\begin{array}{l}28.5 \\
20.5 \\
\text { Oct }\end{array}$ & $\begin{array}{l}41 \\
33 \\
\text { Oct }\end{array}$ & $\begin{array}{l}53 \\
45 \\
\text { Oct }\end{array}$ \\
\hline $\begin{array}{l}\text { Controls ( } 3 \text { colts) } \\
\text { (SEM) }\end{array}$ & $\begin{array}{l}3.33 \\
(0.33)\end{array}$ & $\begin{array}{c}3.33 \\
(1.32)\end{array}$ & $\begin{array}{c}4.33 \\
(1.67)\end{array}$ & $\begin{array}{c}2.00 \\
(0.58)\end{array}$ & $\begin{array}{l}1.67 \\
(0.33)\end{array}$ & $\begin{array}{c}0.33 \\
(0.33)\end{array}$ \\
\hline $\begin{array}{l}1 \mathrm{mg} / \mathrm{kg} \text { every } 3 \text { rd week ( } 3 \text { colts) } \\
\text { (SEM) }\end{array}$ & $\begin{array}{c}2.67 \\
(0.33)\end{array}$ & $\begin{array}{c}2.33 \\
(0.33)\end{array}$ & $\begin{array}{c}5.33 \\
(0.33)\end{array}$ & $\begin{array}{c}2.67 \\
(1.67)\end{array}$ & $\begin{array}{c}2.33 \\
(0.33)\end{array}$ & $\begin{array}{c}0.66 \\
(0.33)\end{array}$ \\
\hline
\end{tabular}

Table 8. Number of colts with closed epiphyseal plates at different times in experiment III.

\begin{tabular}{lllll}
\hline Age of colts (months) & 22 & 24 & 25 & 26 \\
Months after treatment & 14 & 16 & 17 & 18 \\
\hline Controls (3 colts) & $0 / 3$ & $2 / 3$ & $3 / 3$ & $3 / 3$ \\
$1 \mathrm{mg} / \mathrm{kg}$ every 3rd week (3 colts) & $0 / 3$ & $0 / 3$ & $2 / 3$ & $3 / 3$ \\
\hline
\end{tabular}

group, and $132 \mathrm{sec}$ and $88 \mathrm{sec}$ in the treated group at the same time points) and long during the nonbreeding season $(208 \mathrm{sec}$ at 2 years of age, and $178 \mathrm{sec}$ at 3 years of age in the control group, and $232 \mathrm{sec}$ and $186 \mathrm{sec}$ in the treated group at the same time points). At 2 years of age, the time was long also during the breeding season, $228 \mathrm{sec}$ in the control group, and 382 $\mathrm{sec}$ in the treated group. There were no statistically significant differences between the groups.

Closure of the right distal radial growth plate occurred slightly earlier in the control group than in the treated group ( 2 out of 3 and 0 out of 3 , respectively, at 24 months of age and 3 out of 3 and 2 out of 3 , respectively, at 25 months of age) but the difference was not statistically significant (Table 8).

\section{Discussion}

The animals in the 3 experiments were treated at different ages, during different years, and examined after different time intervals. Compari- sons between the experiments are therefore impossible. Discussion of the results focuses on differences within each experiment.

Serum testosterone concentrations follow a seasonal pattern in stallions. Values are low from August to December and high from March to June (Burns et al. 1984, Clay et al. 1988). The results of experiment III confirm these findings. Testosterone concentrations were higher during the breeding season at 2 years of age than during the nonbreeding season at 2, 3 and 4 years of age. In control animals in October at 2 years of age testosterone concentration was high $(23.5 \mathrm{nmol} / \mathrm{l})$ in experiment $\mathrm{I}$, but low $(2.0$ $\mathrm{nmol} / \mathrm{l}$ ) in experiment III. The social status of a colt in relation to other males (harem male vs. bachelor male) can markedly affect serum testosterone concentrations (McDonnel \& Murray, 1995). The social status was not examined in the present study. Testosterone measurements done in different years may not be comparable. It is unknown what effect variations in weather, nutrition and management might have on hormone levels. 
Four and a half months after the final treatment in experiment I and II testosterone levels were much lower in colts injected with $500 \mathrm{mg}$ every 3 rd week or $1 \mathrm{mg} / \mathrm{kg}$ every 3 rd week, respectively, than in controls. It is not known when testosterone levels started to decrease, because testosterone levels were not measured during steroid treatments. Other studies in which anabolic steroids have been given to stallions have shown no decreases in testosterone levels during courses of treatment. Carson \& Thompson (1979) gave monthly injections of $1.1 \mathrm{mg} / \mathrm{kg}$ of boldenone undecylenate for 6 months to colts, starting at ages 15 to 17 months, i.e. at ages similar to those in our experiment I. Testosterone values were higher in the treated group than in the control group when testosterone was determined at two-week intervals (Carson \& Thompson 1979). Garcia et al. (1987) administered stanozolol or boldenone undecylenate, every 3rd week or every week, to 2- to 16-yearold stallions. Anabolic steroids did not decrease testosterone levels. The highest levels in fact occurred in the group that had received 0.55 $\mathrm{mg} / \mathrm{kg}$ boldenone undecylenate every week. Testosterone was determined in every week blood samples without hCG administration.

Two years after treatments, hCG-induced testosterone levels were much higher in colts treated in experiment $I$ than in untreated controls. It is not known whether testosterone levels remained permanently increased. In experiment III, serum testosterone levels were similar in the treated and control groups at all times. However, these animals were examined for the first time as late as 10 months after cessation of treatment. Either there were no effects or they had disappeared by the time of the first examination. No "rebound" phenomenon was found in these colts, which may indicate that there was no effect at all.

We found no difference between groups in respect to libido, as judged by time to ejaculation.
This finding is in agreement with the findings of Squires et al. (1981, 1982). It is logical that time to ejaculation is long at 2 years of age and during the nonbreeding season. Individual variations in time to ejaculation are large, and statistically significant differences are therefore difficult to demonstrate, especially in young animals without sexual experience.

Closure of radial distal growth plates has been reported to take place in Thoroughbred and Standardbred horses at 25-28 and 28-31 months of age, respectively (Dietz et al. 1988). Two control colts in our experiment III had closed growth plates as early as at 24 months, and one control colt in our experiment II as late as at 30 months of age. Nutrition and management could explain this difference between colts born in different years. The results of our experiments indicate that anabolic steroid treatment did not cause premature closure of epiphyseal growth plates. It was observed that colts treated with anabolic steroids in fact exhibited open growth plates more often than the controls. If anabolic steroids are given at an early age, or treatment is stopped shortly before the critical time for closure of the growth plates, serum testosterone levels may be low, and delay closure. This observation is important since colts treated with anabolic steroids before or during training will be more susceptible to cartilage injury.

In conclusion, anabolic steroid treatment has long-term effects on reproduction. It can influence serum testosterone concentration for years after cessation of treatment. Further, steroid treatment can delay the closure of growth plates. Colts treated with anabolic steroids may suffer cartilage injury, if intensive training is started soon after or during the treatment. Although some effects of anabolic steroid treatment can be reversible, we advice that anabolic steroids are not used in order to improve performance. 


\section{References}

Blanchard TL: Some effects of anabolic steroids especially on stallions. Comp. Cont. Educ., 1985, 7, 372-380.

Burns PJ, Jawad MJ, Weld JM, Kaufman WC, Witherspoon DM, Wilson EA, Douglas RH: Effects of season, age and increased photoperiod on reproductive hormone concentrations and testicular diameters in thoroughbred stallions. Eq. vet. Sci., 1984, 4, 202-208.

Carson RL, Thompson FN: Effects on an anabolic steroid on the reproductive tract in the young stallion. J. Eq. Med. Surg., 1979, 3, 221-224.

Clay CM, Squires EL, Amann RP, Nett TM: Influences of season and artificial photoperiod on stallions: luteinizing hormone, follicle-stimulating hormone and testosterone. J. Anim. Sci., 1988, 66, 1246-1255.

Davis LE: Anabolic steroids in the horse. J. Amer. vet. med. Ass., 1981, 179, 278-280.

Dietz $O$, Nagel E, Schwede H: Zur Problematik der Epiphysenreifung beim Pferd (Problems in growth plate closure in the horse). Prakt. Tierarzt, 1988, 69, 21-27.

Ganjam VK: Episodic nature of the $\Delta^{4}$-ene and $\Delta^{5}$ ene steroidogenic pathways and their relationships to the adreno-gonadal axis in stallions. J. Reprod. Fert., 1979, Suppl. 27, 67-71.

Garcia MC, Ganjam VK, Blanchard TL, Brown E, Hardin K, Elmore RG, Youngquist RS, Loch WE, Ellersieck MR, Balke JM: The effects of stanozolol and boldenone undecylenate on plasma testosterone and gonadotropins and on testis histology in pony stallions. Theriogenology, $1987,28,109$ 119.

Herring DS: Radiographic evaluation of the distal radial physis of horses treated with anabolic steroids. Proc. Symp. Anab. Steroids in Eq. Med., Columbia, Missouri, 1981, 18-20.

Maher JM, Squires EL, Voss JL, Shideler RK: Effect of anabolic steroids on reproductive function of young mares. J. Amer. vet. med. Ass., 1983, 183, 519-524.

McDonnel SM, Murray SC: Bachelor and harem stallion behavior and endocrinology. Biol. Reprod. Mono 1, 1995, 577-590.

Saastamoinen $M$, Koskinen $E$ : Influence of quality of dietary protein supplement and anabolic steroids on muscular and skeletal growth of foals. Anim. Prod., 1993, 56, 135-144.

Silberzahn P, Zwain I, Guerin P, Benoit E, Jouany $J M$, Bonnaire $Y$ : Testosterone response to human chorionic gonadotropin injection in the stallion. Eq. vet. J., 1988, 20, 61-63.

Squires EL, Berndtson WE, Hoyer JH, Pickett BW, Wallach SJR: Restoration of reproductive capacity of stallions after suppression with exogenous testosterone. J. Anim. Sci., 1981, 53, 1351-1359.

Squires EL, Todter GE, Berndtson WE, Pickett BW: Effect of anabolic steroids on reproductive function of young stallions. J. Anim. Sci., 1982, 54, 576-582.

Tobin T: Pharmacology review: The anabolic steroid androgen group of drugs. J. Equine Med. Surg., $1978,2,163-165$.

\section{Sammanfattning}

Inverkan av 19-norandrostenololylaurat på serumkoncentrationen av testosteron, libido och tillslutningen av den distala tillväxtzonen $i$ radius hos unga hingstföl.

Tre experiment utfördes där inverkan av den anabola steroiden 19-norandrostenololylaurat på serum testosteron, libido och tillslutningen av den distala tillväxtzonen i radius undersöktes hos hingstföl av olika ålder. I det första experimentet erhöll fyra hingsföl $500 \mathrm{mg}$ och likaså fyra hingstföl $100 \mathrm{mg}$ var tredje vecka. Djuren var 12-16 månader gamla i början och 24 månader gamla i slutet av experimentet. Sex djur tjänstgjorde som kontroller. I det andra experimentet behandlades fyra hingstföl med 1 $\mathrm{mg} / \mathrm{kg}$ var tredje vecka och ytterligare fyra hingstföl med $0.3 \mathrm{mg} / \mathrm{kg}$ varje vecka. Dessa djur var 7 månader gamla $\mathrm{i}$ början och 12 månader gamla i slutet av experimentet. Sex hingstföl i samma ålder ingick som kontrollgrupp. I det tredje experimentet gavs $1 \mathrm{mg} / \mathrm{kg}$ var tredje vecka till tre föl som var 3-8 månader gamla.

Efter att behandlingarna avslutats följdes djurens libido och HcG-inducerade koncentration av serum testosteron ända tills djuren uppnått en ålder mellan 3 och 4 år. Då djuren var mellan 22 och 36 månader gamla fastställdes huruvida radius distala tillväxtzon tillslutits. De behandlade fölen hade lägre testosteron nivåer 4.5 månader efter avslutad behandling $\mathrm{i}$ experiment I $(\mathrm{p}<0.001)$ och II $(\mathrm{p}<0.05)$ än kontrolldjuren. Två år efter behandlingarna i experiment I var de hCG-inducerade serum testosteron nivåerna mycket högre hos de behandlade hingstfölen än de obehandlade hingstfölen. Behandlingen påverkade inte hingstarnas libido. $\mathrm{Ej}$ heller tydde något $\mathrm{av} \mathrm{ex}-$ 
perimenten på att behandlingen skulle leda till att de epifysiala tillväxtzonerna tillsluts prematurt, snarare tvärtom. Fyra och en halv månad efter avslutad behandling i experiment I hade endast en liten del av hingstfölen tillslutna tillväxtzoner (0/4 hingstar i 500 mg gruppen och $2 / 5$ i $100 \mathrm{mg}$ gruppen). De flesta hingstarna i den obehandlade gruppen hade däremot tillslutna tillväxtzoner $(5 / 6)(p<0.05)$. Sammanfattningsvis kan konstateras att anabola steroiden har en långvarig inverkan på reproduktionen. Deras inverkan på serum testosteron kan kvarstå i flera år efter avslutad behandling och de kan fördröja tillslutningen av epifysiala tillväxtzonerna, vilket kan leda till ökad risk av broskskador under träning.

(Received March 21, 1996; accepted November 6, 1996).

Reprints may be obtained from: Erkki Koskinen, Agricultural Research Centre, Equine Research, Varsanojantie 63, 32100 Ypäjä, Finland. E-mail: erkki.koskinen@mtt.fi, fax: +35827602260. 
